\title{
Unusual presentations of Churg Strauss syndrome in paediatrics: a tale of 2 masses from one centre experience
}

\author{
E Baildam, C Pain, F McErlane, G Cleary, M Beresford, L McCann \\ From 18th Pediatric Rheumatology European Society (PReS) Congress \\ Bruges, Belgium. 14-18 September 2011
}

\section{Background}

To highlight unusual presentations of Churg Strauss Syndrome (CSS) in children.

\section{Aim}

Raising clinical awareness of atypical presentations.

\section{Methods}

Case note review and literature search.

\section{Results}

\section{Case 1}

A 15 year old girl with worsening asthma and rhinitis presented with a persistent 10x6 cm breast lump 6 months after starting Montelukast. Chest X-rays and CT scan were normal, maxillary sinuses congested, with absolute eosinophilia of $2.4 \times 10^{9} /$ l, ESR normal, no proteinuria). On needle biopsy, dilated ducts contained necrotic eosinophilic debris, intense infiltrate of eosinophils and plasma cells without granulomatous infiltration or vasculitis. Despite withdrawing Montelukast the mass persisted but treatment with steroids was successful.

\section{Case 2}

A 14 year old girl presented with worsening asthma associated with malaise, weight loss, an intermittent vasculitic rash and abdominal pain. She had a large right ventricular mass with pericardial effusion and endocardial impairment, pulmonary infiltrates, microscopic haematuria, vasculitic changes on cerebral MRI, a raised eosinophil count $\left(6.16 \times 10^{9}\right)$, anaemia, ESR 114 and positive pANCA (non PR3 / MPO). A good clinical response to treatment with steroids, cyclophosphamide (IV) and immunoglobulin is currently maintained on MMF and low dose steroid with anticoagulation (warfarin). Her cardiac mass has not regressed, but remained static, most likely representing chronic endocardial fibrosis.

\section{Conclusion}

These cases illustrate atypical presentations of CSS in children. Eosinophilic mastitis may be idiopathic, parasitic or part of CSS - reported following treatment with Montelukast but never with eosinophilic mastitis. Cardiac masses in CSS have been reported occasionally in adults, but not previously seen in children.

Published: 14 September 2011

doi:10.1186/1546-0096-9-S1-P96

Cite this article as: Baildam et al:: Unusual presentations of Churg Strauss syndrome in paediatrics: a tale of 2 masses from one centre experience. Pediatric Rheumatology 2011 9(Suppl 1):P96.

Submit your next manuscript to BioMed Central and take full advantage of:

- Convenient online submission

- Thorough peer review

- No space constraints or color figure charges

- Immediate publication on acceptance

- Inclusion in PubMed, CAS, Scopus and Google Scholar

- Research which is freely available for redistribution 